3. Korsak, K. (2001). Pedahohika novoho stolittia [Pedagogy of the new century]. Native school, No. 10, pp. 13-17. [in Ukrainian].

4. Lutsyk, D. \& Stakhiv, L. (2011). Pedahohichni tekhnolohii: navch. posibnyk [Pedagogical technologies: textbook. manual]. Drohobych: Editorial and Publishing Department of Drohobych Ivan Franko State Pedagogical University, 160 p. [in Ukrainian].

5. Oliinyk, V. (2011). Systema pedahohichnoi osvity ta pedahohichnoi innovatsii [The system of pedagogical education and pedagogical innovation]. School Director, No. 4, pp. 61-70. [in Ukrainian].
6. Ostapchuk, O. (2004). Rozvytok pedahohichnykh system $v$ umovakh modernizatsii osvity [Development of pedagogical systems in terms of modernization in education]. The path of education, No. 1, pp. 611. [in Ukrainian].

7. Khymynets, V. \& Kiryk, M. (2009). Innovatsii v pochatkovii shkoli: navch. posibnyk [Innovations in primary school: textbook. Manual]. Ternopil, 308 p. [in Ukrainian].

8. Kreatyvnist: Internet-resurs [Creativity: Internet resource]. Available at: https:// sites.google.com/site/kreativnist/ [in Ukrainian].

Стаття надійшла до редакції 17.08.2021

УДК 378.147 .88

DOI:

Олена Шарапова, кандидат педагогічних наук, доцент кафедри педагогіки, іноземної філології та перекладу Харківського національного економічного університету імені Семена Кузнеия

\title{
МОВНО-КОМУНІКАТИВНА КОМПЕТЕНТНІСТЬ ЯК БАЗИС САМОРЕАЛІЗАЦІЇ СУЧАСНОГО ВЧИТЕЛЯ
}

У статті узагальнено практику реалізації холістичного підходу у прочесі опанування освітньої програми Освітологія здобувачами другого (магістерського) рівня вищої освіти.

Автором виділено алгоритм втілення холістичного підходу в роботі зі здобувачами вищої освіти: зв'язність, включення, рівновага.

Складники мовно-комунікативних компетентностей: розуміння ролі таких компетентностей в забезпеченні якості освіти, комплекс загальних і предметних / фахових компетентностей для взаємодіі вчителя з людьми, роботі у команді, донесення інформаиії, вмінь вчитися упродовж життя у суспільстві знань - узмісті навчальних програм.

Ключові слова: вчитель; компетентність; мовно-комунікативна; освітня програма; освітологія; саморелізація; студентозорієнтоване навчання; холістичний підхід; якість освіти.

Jim. 8.

Olena Sharapova, Ph.D.(Pedagogy), Associate Professor of the Pedagogy, Foreign Philology and Translation Department Kharkiv Semen Kuznets National University of Economics

\section{LANGUAGE AND COMMUNICATIVE COMPETENCE AS A BASIS OF SELF- REALIZATION OF THE MODERN TEACHER}

In the article the author reveals the vision of linguistic and communicative competence through the prism of a holistic approach. It is noted that this approach involves the creation of an educational space for the selfrealization of the individual. The modern teacher works a priori ahead of time. Professional activity in the information, communication, and technologically rich educational environment of the educational institution requires perfection in mastering language and communication competencies.

From the standpoint of a holistic approach, the algorithm for the formation of linguistic and communicative competence of the modern teacher is distinguished: the creation of logical and causal relationships in a particular cycle of study or during mastering the educational-professional program of a certain level of higher education; the use of innovative technologies, the use of a wide range of communicative techniques of verbal and nonverbal codes in the scientific and pedagogical interaction of participants in the educational process; balance during the recognition and support of the cognitive component of educational and cognitive and research activities of applicants for higher pedagogical education.

The article specifies the components of language and communication competencies of a modern teacher: understanding the role of such competencies in ensuring the quality of education, a set of general and subject $/$ professional competencies that will provide a sufficient level of constructive interaction between teachers and 
people, teamwork, informing others, and assessment systems, lifelong learning skills, citizen skills of the knowledge society.

The uniqueness of the educational program Osvitology is determined: the right of applicants to a personal professional development program, if mastered according to an individual schedule, the use of language and communication competencies in the process of restorative or supportive learning, dissemination of communication management practices, initiatives of supervisors, coaches and mentors by stakeholders.

Keywords: teacher; competence; linguistic and communicative; educational program; osvitology, selfrealization; student-oriented learning; holistic approach; quality of education.

П остановка проблеми. Усі трансформаційні процеси, що відбуваються в суспільстві, зосереджені навколо інформаціїі суспільства знань. Ці імперативи визначають загальний вектор самореалізації сучасного учителя, який успішно здійснює освітній процес в інформаційно-комунікаційному технологічно насиченому освітньому середовищі закладу освіти. Національна політика щодо реформування вищої педагогічної освіти в Україні [2] спрямована на піднесення статусу українського вчителя. Однак реалізації глобальних цілей сприятимуть не лише послідовні підтримувальні заходи 3 боку уряду i державотворців. Вирішальне значення має діяльне усвідомлення науковою і професійною педагогічною спільнотою нових завдань загальної і предметної підготовки майбутніх учителів. У цьому контексті виразно прослідковується доцільність розгляду мовно-комунікативної компетентності 3 огляду на багатовимірність i комплексний характер власне самого явища самореалізації сучасного вчителя.

Аналіз основних досліджень і публікацій. Зазначимо тут, що холістичний підхід передбачає створення такого освітнього середовища, в якому якнайповніше розкривається цілісність особистості, яка здатна сприймати інформацію i сприймає ¥ї через поєднання фізичного, інформаційно-комунікаційного, емоційно-етичного, аудіально-візуального, когнітивного і духовного джерел представлення такої інформації [7]. Відповідно актуального звучання набуває, на наш погляд, звернення до глибокого багатофакторного аналізу мовно-комунікативної компетентності для особистісної і професійної самореалізації.

У контексті досліджуваної проблеми цікаві міркування і результати аналізу публікації Г. Дмитренко, Е. Помиткіна, Н. Головач (2020) [4], в якій автори детально проаналізували особливості підготовки учителя, здатного не лише набувати компетентностей, але й продукувати нове знання, інноваційний досвід. Цікавим у контекстному аналізі заявленої проблеми видається публікація І. Гоцинець (2021) [3], де авторкою розкрито значимість використання ресурсу соціальних мереж у формуванні комунікативної компетентності вчителя. Однак багатоаспектність, динамічність розуміння і процесуальність мовно-комунікативної компетентності вчителя потребує подальшого вивчення, зокрема 3 позицій холістичного підходу.

Формування мети. Мета статті: розкрити мовно-комунікативну компетентність як базис самореалізації сучасного вчителя через призму холістичного підходу.

Виклад основного матеріалу. Цілком погоджуємося із одним із ініціаторів поширення в педагогіці холістичного підходу Д. Міллером [7] у пропозиціях реалізувати цей підхід через такі характеристики освітнього середовища.

Перша характеристика: зв'язність. Вона передбачає творення логічних і причинновонаслідкових зв'язків на конкретному циклі навчання. Так, у формуванні тіла освітньої програми “Освітологія", 3011 - освітні, педагогічні науки, другий магістерський рівень вищої освіти [8], важливим моментом було розроблення структурно-логічної схеми. Гарантом освітньої програми доктором педагогічних наук, професоркою кафедри освітології та інноваційної педагогіки Харківського національного педагогічного університету імені Г.С. Сковороди Л. Зеленською [6] було акцентовано увагу на дотриманні чіткої і відкритої для розуміння здобувачами і стейкхолдерами логіки вивчення дисциплін загального циклу, професійного спрямування, презентованих дисциплін вільного вибору і різновидів практик. Усі сформовані логічні зв'язки у структурно-логічній схемі ОПП узгоджені із запитами стейкхолдерів і аналітикою запитів абітурієнтського середовища [5].

Навчальний план ОПП сформовано відповідно до актуальних напрямків державної політики в галузі освіти, розвитку регіональної освіти, соціальному запиту і потреб освітнього закладу, з опорою на оцінку ступеня інноваційності ідей, ясності їх викладу, розуміння способів реалізації задуму [5].

Друга характеристика реалізації холістичного концепту в процесі формування мовнокомунікативної компетентності вчителя передбачає включення. По суті, це застосування у реалізації освітніх компонент програми широкого спектру навчальних підходів для людей 3 різними потребами. Зокрема, в заявленій ОПП 
“Освітологія" зазначено, що навчальний процес спирається на використання інноваційних технологій, застосування широкого спектру комунікативних прийомів вербальних і невербальних кодів у науково-педагогічній взаємодії учасників освітнього процесу [8]. Унікальність цієї ОПП прослідковується в дотриманні не лише студентоцентрованого підходу, але й трансдисциплінарного навчання i забезпеченні підтримки здобувачів у розробленні і реалізації індивідуальної освітньої траєкторії успіху через власне включення до роботи в наукових школах університету, ініціативи та івенти на рівні діяльності університету в напрямі інтернаціоналізації освіти [сайт кафедри].

Запропонований у ОПП “Освітологія” спектр форм навчання і викладання свідчить про зорієнтованість на формування і використання в новій ситуації мовно-комунікативної компетентності (ЗК5, ЗК6, СК12, СК13, СК21, СК22) [6; 8], зокрема: “ініціативного самонавчання на засадах корпоративної співпраці, з елементами дуального навчання" [там само]. Включенню як значимому моменту реалізації холістичного концепту мовнокомунікативної компетентності сприяють практичні заняття з використанням IКТ, ресурсів дистанційної освіти на платформі MOODLE, навчальні проєкти, тренінги. Ці форми дають можливість здобувачам реалізувати індивідуальну програму самореалізації.

Сучасний учитель повинен не лише технологічно грамотно застосувати мовнокомунікативні компетентності, допомагати своїм учням набути досвіду використання їх для успішної співпраці, розв'язування проблемних завдань у процесі навчання упродовж життя. Для цього в структурі освітнього процесу відповідна група компетентностей прослідковується у таких компонентах.

Перший компонент: розуміння ролі мовнокомунікативних компетентностій у забезпеченні якості освіти. Він передбачає ознайомлення учасників освітнього процесу під час опанування ОК “Філософія освіти”, "Продуктивна педагогіка”, “Актуальні зарубіжні та вітчизняні освітні концепції”, з векторами освітньої політики, виявлення причинново-наслідкових зв'язків, формування педагогічного оптимізму (робота на випередження, позитивне сприйняття трансформаційних процесів, що відбуваються в освіті, педагогічних науках. Це дасть змогу демонструвати розуміння і конструктивні дії в опануванні нових знань. Зі свого боку, конструктивна педагогічна діяльність слугує базисом прояву ініціатив в інноваційній освітній діяльності здобувачів, представників громади, стейкхолдерів, інших зацікавлених в якості освіти осіб.

Наступним компонентом у структурі мовнокомунікативних компетентностей учителя є базові елементи змісту навчальних програм і систем оцінювання. Так, якість освіти залежить від чіткого визначення загальних і предметних / фахових компетентностей, які забезпечать достатній рівень конструктиву у взаємодії вчителя 3 людьми, роботі у команді, донесення інформації іншим зрозуміло, достовірно, вичерпно і однозначно [1]. Тому цей компонент виразно прослідковується у розробленні відповідного змісту освітньої програми з опорою на чіткі, визначені в логічній послідовності, вимірювані, ревалентні запити працедавців та очікувані результатами навчання. Важливим моментом, на наш погляд, $є$ уведення у зміст освітніх програм компетентностей і програмних результатів, які спрямовані на формування вмінь вчитися упродовж життя, умінь громадянина суспільства знань.

Синтезуючим моментом в холістичному підході є рівновага у значенні розпізнавання та підтримки когнітивного компоненту навчальнопізнавальної і науково-дослідницької діяльності здобувачів. На цьому етапі розроблення ОПП цикл дисциплін загальної підготовки, дисципліни вільного вибору зорієнтовані саме на формування осмисленого розуміння учителями суті і специфіки інноваційних педагогічних технологій, формуванням комплексу умінь і навичок, застосуванням їх у структурі власної професійної діяльності. Тому в освітній програмі Освітологія передбачено низку інтеракцій. Зокрема:

А. Організація педагогічних практик з огляду на групи мовно-комунікативних компетентностей. Наскрізні навчальні програми виробничих, навчальних практик містять комплекс заходів, спрямованих на використання IКТ, розв'язання комплексних завдань у тандемі заклад освіти організація, структура виробничого спрямування, види і форми самоосвітньої роботи, просвітницькі стартапи, популяризація актуального досвіду залученості здобувачів до наукових шкіл, які утворені науково-педагогічними працівниками 3 групи забезпечення.

В. Створення умов для освоєння технічних $\mathrm{i}$ програмних засобів інформаційно-комунікаційних технологій через використання базових інструментів і застосунків, функціонування освітньої платформи онлайн навчання, дидактичного потенціалу складних інструментів.

С. Оновлення управління освітнім процесом, що, власне, передбачає використання ефективних практик адміністрування і самоврядування у 
традиційних формах навчальної роботи, підтримка ініціатив створення груп співпраці на міждисциплінарному, міжгалузевому рівнях, перетворення закладу освітина організацію, яка навчає, здійснює комплексно систему заходів 3 підвищення кваліфікації, неформальної, інформальної освіти.

D. Програми професійного розвитку здобувачів, які опановують ОПП Освітологія за індивідуальним графіком, передбачають використання мовнокомунікативних компетентностей у процесі заходів відновлювального чи підтримувального навчання, поширення практик комунікативного менеджменту, ініціативи супервізорів, коучів і менторів в організації допомоги і наставництва з боку стейкхолдерів, інших зацікавлених осіб.

Висновки 3 даного дослідження i перспективи подальших розвідок у даному напрямку. Підсумовуючи викладене у статті, зазначимо, майстерне опанування мовнокомунікативними компетентностями сприятиме піднесенню іміджу учителя як майстра учіння, представника соціальної еліти. Актуалізація холістичного підходу в процесі реалізації освітньопрофесійних програм, галузь знань - освітні, педагогічні науки, передбачає врахування у програмних результатах навчання раціонального осмислення духовної і матеріальної діяльності ресурсами мовних і немовних кодів, цінностей.

Апріорно мовно-комунікативні компетентності $\epsilon$ базисом самореалізації сучасного учителя у процесі творення відкритої системи неперервного професійного зростання особистості упродовж життя та вибудовування відповідно життєвих пріоритетів на цьому шляху. Розроблення i реалізація структур таких відкритих систем $\epsilon$ перспективою подальшої наукової, теоретичної і методичної розвідки.

\section{ЛIТЕРАТУРА}

1. Explaining the European Qualifications Framework for Lifelong Learning. URL: https://ec.europa.eu/ploteus/ sites/eaceqf/files/brochexp en.pdf

2. Всеукраїнський форум "Україна 30 . Освіта i наука" 31.05.2021. URL: https://mon.gov.ua/ua/news/ vseukrayinskij-forum-ukrayina-30-osvita-i-nauka-sergijshkarlet-prezentuvav-koncepciyu-prezidentskogouniversitetu

3. Гоцинець І. Соціальні мережі як додатковий інструмент формування іншомовної інформаційно-комунікативної компетентності студентів. Молодь і ринок. № 4/190 (2021). DOI:https://doi.org/10.24919/2308-4634.2021.236349

4. Дмитренко Г., Помиткін Е., Головач Н. Формування здатних до самореалізації здобувачів освіти в умовах глобалізованого світу. Молодь іринок. 2020. №1/180. С. 12-18.

5. Зеленська Л. Д., Ворожбіт-Горбатюк В. В. Алгоритм моніторингу запитів цільової аудиторії магістерських програм спеціальності “Освітні, педагогічні науки". Абітурієнтське середовище періоду глокалізації: шляхи формування та тенденціі розвитку: Матеріали XIX Міжнар. наук.-практ. конф., Харків, 12 лют. 2021 р. Харків: Вид-во НУА, 2021. С.78-81.

6. Кафедра освітології та інноваційної педагогіки ХНПУ імені Г.С. Сковороди. URL: https://www.kafpedagogy-hnpu.com/

7. Миллер Д. Холистическое образование. Первое сентября. Первая тетрадь. Политика образования. URL: http://ps.1 september.ru/article.php?ID=200205007

8. Освітньо-професійнапрограма “Освітологія”.URL:http:/ /smc.hnpu.edu.ua/files/Osv\% D1\%96tn \%D1\%96 programi/ Osvitni programu magistr/2021 rik/Osvitologiya.pdf

\section{REFERENCES}

1. Explaining the European Qualifications Framework for Lifelong Learning (2021). Available at: https://ec.europa.eu/ ploteus/sites/eaceqf/files/brochexp_en.pdf [in English].

2. Vseukrainskyi forum "Ukraina 30. Osvita i nauka" 31.05.2021. [All-Ukrainian Forum "Ukraine 30. Education and Science". Available at: https://mon.gov.ua/ua/news/ vseukrayinskij-forum-ukrayina-30-osvita-i-nauka-sergijshkarlet-prezentuvav-koncepciyu-prezidentskogouniversitetu [in Ukrainian].

3. Hotsynets, I. (2021). Sotsialni merezhi yak dodatkovyi instrument formuvannia inshomovnoi informatsiino-komunikatyvnoi kompetentnosti studentiv [Social networking sites as an additional means for formation of foreign language information and communicative competence of students]. Youth \& market. No. 4/190 (2021). DOI: https://doi.org/10.24919/23084634.2021.236349 [in Ukrainian].

4. Dmytrenko, H., Pomytkin, E. \& Holovach, N. (2020). Formuvannia zdatnykh do samorealizatsii zdobuvachiv osvity v umovakh hlobalizovanoho svitu [Formation of self-fulfilling students in a globalized world]. Youth \& market. No.1/180. pp. 12 - 18. [in Ukrainian].

5. Zelenska, L. D. \& Vorozhbit-Horbatiuk, V. V. (2021). Alhorytm monitorynhu zapytiv tsilovoi audytorii mahisterskykh prohram spetsialnosti "Osvitni, pedahohichni nauky" [Algorithm for monitoring the requests of the target audience of master's programs in "Educational, pedagogical sciences"]. The entrant environment of the glocalization period: ways of formation and development trends. Kharkiv, pp.78-81. [in Ukrainian].

6. Kafedra osvitolohii ta innovatsiinoi pedahohiky KhNPU imeni H.S. Skovorody (2021) [Education and Innovative Pedagogy Department, Kharkiv Hryhoriy Skovoroda National Pedagogical University]. Available at: https://www.kaf-pedagogy-hnpu.com/ [in Ukrainian].

7. Miller, D. (2001). Holisticheskoe obrazovanie [Holistic education]. The first of September. First notebook. Education policy. Available at: https:// ps.1 sept.ru/article.php?ID=200205007 [in Russian].

8. Osvitno-profesiina prohrama "Osvitolohiia" [Educational and professional program "Education"]. Available at: http://smc.hnpu.edu.ua/files/Osv\%D1\% 96t n\%D1\%96 programi/Osvitni programu magistr/2021 rik/ Osvitologiya.pdf[in Ukrainian].

Стаття надійшла до редакції 27.08.2021 